\title{
Peach and Cherry Agroindustrial Wastes: New and Economic Sources for the Production of Lignocellulolytic Enzymes
}

\author{
Merve Akpinar ${ }^{1}$ and Raziye Ozturk Urek ${ }^{2}$ * \\ ${ }^{1}$ Chemistry Department, Graduate School of Natural and Applied Sciences, Dokuz Eylül University, 35160 Buca, Izmir, Turkey. \\ ${ }^{2}$ Chemistry Department, Biochemistry Division, Faculty of Science, Dokuz Eylül University, 35160 Buca, Izmir, Turkey \\ * Corresponding author: E-mail: raziye.urek@deu.edu.tr \\ Tel: +90232301 8689; Fax: +902324534188
}

Received: 06-02-2017

\begin{abstract}
Pleurotus eryngii was incubated on both peach and cherry agroindustrial wastes by solid state fermentation for 30 days without/with pretreatment conditions. The lignocellulosic substrates were pretreated with dilute acid and alkaline solutions, hot water before incubation. The maximum carboxymethyl cellulase and xylanase activities peaked on $3^{\text {rd }}$ and $5^{\text {th }}$ days under control conditions of both wastes, respectively. The highest laccase and manganese peroxidase activities reached to their maximum on $17^{\text {th }}$ day as $2193.06 \pm 50.4 \mathrm{UL}^{-1}$ and $732.73 \pm 19.8 \mathrm{UL}^{-1}$, respectively. The highest aryl alcohol oxidase activity was obtained as $239.25 \pm 7.3 \mathrm{UL}^{-1}$ in control condition of peach cultures. The used pretreatment methods had generally negative effects on lignocellulolytic enzyme production. The highest lignocellulolytic activities were detected using peach wastes. To results, these wastes could be used as alternative, new and economic energy sources to produce high amounts of lignocellulolytic enzymes.
\end{abstract}

Keywords: Agroindustrial wastes, lignocellulolytic enzymes, Pleurotus eryngii, pretreatment, solid state fermentation.

\section{Introduction}

Lignocellulosic substrate from forestry, agricultural and agroindustrial wastes is abundant, renewable and inexpensive energy sources for the production of various value added products, such as ethanol, food additives, organic acids, enzymes, and others due to their chemical composition based on sugars and other compounds of interest. ${ }^{1}$ Also, the accumulation of lignocellulosic wastes in large quantities causes environmental problems when they could not be used for the production of these products. ${ }^{1,2}$

Bioconversion of lignocellulosic substrate to value added products is so difficult to its tertiary architecture consisting of primarily cellulose, hemicelluloses and lignin that are strongly intermeshed and chemically bonded by non-covalent forces and by covalent crosslinkages. Selective organisms, especially white rot fungi (WRF), can efficiently degrade lignocelluloses. ${ }^{2}$ This degradative ability of WRF is due to their extracellular hydrolytic and ligninolytic enzyme systems. For lignocellulose bioconversion, the hydrolytic enzyme systems are divided into two groups: cellulolytic and hemicellulolytic, which contain carboxymethyl cellulase (endo-1,4- $\beta$-glucanase; CMCase), exo-1,4- $\beta$-glucanase, $1,4-\beta$-glucanase and xylanases. Another enzyme system is ligninolytic group, which includes laccase (Lac), manganese peroxidase $(\mathrm{MnP})$, lignin peroxidase $(\mathrm{LiP})$ and aryl alcohol oxidase (AAO). The highly specific hydrolytic enzyme systems convert cellulose and hemicellulose carbohydrates into fermentable sugars; hexoses and pentoses. The non-spesific oxidative ligninolytic enzymes catalyze phenolic and non-phenolic compounds in lignin structure. ${ }^{3}$

The lignocellulose-based biotechnological applications such as biopulping, biobleaching, decolorization, degradation of environmental contaminants, etc. require low cost and large scale enzymes due to increasing demand for markets. ${ }^{4}$ Solid state fermentation (SSF) stands out in the production of lignocellulolytic and other industrially important enzymes. Examples of enzymes produced by different organisms such as Bacillus sp., Pleurotus sp., Aspergillus sp., Trametes spp., etc. under SSF using different sub- 
srates, wheat bran, wheat straw, apple pomace, rice straw, sugarcane bagasse, include laccase, cellulose, lipase, pectinase, protease, xylanase, amylase, etc. ${ }^{5}$ SSF, an alternative culture method, has several advantages over the conventional submerged ones, like higher yields of enzymes. Generally, this process was carried out by using lignocellulosic wastes used as substrates and support material for microbial growth and production of several value added products. ${ }^{4-6}$ The effective utilization of lignocellulosic components would play a significant role in economic enzyme production. For this reason, lignocellulosic substrate sometimes requires pretreatment to improve enzymatic hydrolysis by fungi. The purpose of the pretreatment is to remove lignin and hemicelluloses, reduce cellulose crystallinity, and increase the porosity of the materials. ${ }^{7}$ Pretreatment should ideally involve requirement of low energy with no recycling or environmental costs. ${ }^{8} \mathrm{~A}$ wide range of thermal, mechanical and chemical pretreatment methods and their combinations could be used for efficiently conversion of lignocelluloses. The pretreatment methods may vary depending on the raw material selected, but they could be eco-friendly and not increase the total economy of the bioconversion of the lignocellulosic substrate. ${ }^{8,9}$

The present study evaluated peach and cherry wastes as substrates for production of lignocellulolytic enzymes by Pleurotus eryngii in SSF, and is the first study in this regard. Different agroindustrial wastes were screened for lignocelluloytic enzyme production under SSF, ${ }^{1}$ however peach and cherry wastes have not been reported in production of various industrially important enzymes including lignocelluloytic enzymes by fungi as per the published literature so far. Namely, these wastes were firstly investigated for the production of lignocellulolytic enzymes by P.eryngii, and also the use of them for SSF as substrates with or without any pretreatment conditions. These agro-industrial wastes (with and without pretreatment) were used as major nutritional sources for production of cellulases (carboxymethylcellulase (CMCase), exo-1,4- $\beta$ glucanase, $1,4-\beta$-glucosidase), xylanase and ligninolytic (laccase (Lac), manganese peroxidase (MnP), lignin peroxidase ( $\mathrm{LiP}$ ), aryl alcohol oxidase (AAO)) enzymes by the fungus. Three chemical pretreatment processes including neutral, dilute acid and alkaline, utilized for improving the production of lignocellulolytic enzymes. The study has showed that peach and cherry agroindustrial wastes can serve as important alternative cheap substrates for economic production of lignocellulolytic enzymes by P.eryngii.

\section{Experimental}

\section{1. Lignocellulosic Substrates and Their Chemical Compositions}

Peach and cherry agroindustrial wastes from Dimes fruit juice factory, Izmir, Turkey, were collected and used as the solid substrate for the SSF. According to knowledge from Dimes fruit juice factory, the peach and cherry fruits cultivated in the Aegean region of Turkey were harvested at optimum technological maturity. Their wastes came for two or three pressing to make fruit juice. The chemical compositions of both wastes were analyzed before and after all pretreatment methods. The total carbohydrate, protein and lignin contents of them were colorimetrically determined by the phenol-sulfuric acid method, ${ }^{10}$ Bradford dye-binding assay, ${ }^{11}$ and thioglycolic acid method, ${ }^{12}$ respectively. In addition, cellulose levels after acid hydrolysis in these wastes were determined gravimetrically. ${ }^{13}$

\section{2. Media Preparation}

The white rot fungus $P$. eryngii (DC.) Gillet (MCC58) was used in this study and obtained from Agroma Mushroom Cultivation (Denizli, Turkey). This strain was selected as a suitable organism for bioprocessing of SSF for its potential for higher lignocelluloytic enzyme production. ${ }^{14}$ P. eryngii cultures were maintained on maltpeptone-agar medium at $4 \pm 1{ }^{\circ} \mathrm{C}$ and transferred every month to fresh medium, and then incubated at $25 \pm 1{ }^{\circ} \mathrm{C}$ during 12 day. For enzyme production, untreated peach and cherry agroindustrial wastes and pretreated wastes were used as substrates for growth media. They were stored at $-20 \pm 1{ }^{\circ} \mathrm{C}$ prior to use. SSF was carried out in 100 $\mathrm{mL}$ Erlenmeyer flasks containing $5.0 \mathrm{~g}$ of these wastes as major nutritional sources and $10 \mathrm{~mL}$ of basal culture medium of the following composition per liter: $\mathrm{NH}_{4} \mathrm{NO}_{3}, 2.0$ g; $\mathrm{KH}_{2} \mathrm{PO}_{4}, 0.8 \mathrm{~g} ; \mathrm{K}_{2} \mathrm{HPO}_{4} \times 7 \mathrm{H}_{2} \mathrm{O}, 0.75 \mathrm{~g} ; \mathrm{MgSO}_{4} \times$ $7 \mathrm{H}_{2} \mathrm{O}, 0.5 \mathrm{~g}$; yeast extract, $2.0 \mathrm{~g} ; \mathrm{ZnSO}_{4} \times 7 \mathrm{H}_{2} \mathrm{O}, 0.002 \mathrm{~g}$; $\mathrm{FeSO}_{4} \times 7 \mathrm{H}_{2} \mathrm{O}, 0.005 \mathrm{~g} ; \mathrm{CaCl}_{2} \times 2 \mathrm{H}_{2} \mathrm{O}, 0.06 \mathrm{~g}, \mathrm{CuSO}_{4} \times$ $7 \mathrm{H}_{2} \mathrm{O}, 0.02 \mathrm{~g} ; \mathrm{MnSO}_{4} \times \mathrm{H}_{2} \mathrm{O}, 0.05 \mathrm{~g} .{ }^{15}$ The ratio between amount of solid waste and volume of basal medium was adjusted at 1:2. ${ }^{16}$ The moisture levels of peach and cherry wastes after adding the basal culture medium in this study were $18.41 \pm 1.6$ and $39.73 \pm 3.5 \%$, respectively. Also, the final $\mathrm{pH}$ of the medium was adjusted to 6.0 after sterilization. Three agar plugs $\left(1 \mathrm{~cm}^{2}\right.$ disks $)$ cut from actively growing culture (12 day old), were used as inoculums. The fermentation was carried out in a controlled environment with temperature at $28 \pm 0.5^{\circ} \mathrm{C}$ for 30 days under stationary condition in complete darkness. Under control conditions, the agroindustrial wastes were directly used without any pretreatment methods. Samples from flasks were harvested after 3, 5, 7, 10, 12, 15, 17, 20, 26 and 30 days of cultivation. Experiments were done triplicate and samples were analyzed in triplicate.

\section{3. Pretreatment of Agroindustrial Wastes}

The both peach and cherry wastes, lignocellulosic substrates, were pretreated with dilute acid (sulfuric acid $1.0 \%, \mathrm{w} / \mathrm{v}$ ) and alkaline (sodium hydroxide $1.0 \%$, w/v) solutions, hot water. The hot water treatment was named 
as neutral pretreatment, while alkaline treatments could be named as base pretreatments. At all pretreatment methods, the substrate at a solid loading of $10 \%(\mathrm{w} / \mathrm{w})$ was mixed with pretreatment agents and pretreated at $100{ }^{\circ} \mathrm{C}$ with 60 minutes. And also, the substrate was washed until the $\mathrm{pH}$ adjusted to initial $\mathrm{pH}$ value at dilute acid and alkaline pretreatments for getting the same $\mathrm{pH}$ levels. After pretreatment, the substrate was separated by filtration at room temperature, and then it was ready for the utilization in SSF bioprocess.

\section{4. Enzyme Extraction}

The samples in SSF were mixed with $25 \mathrm{~mL}$ of 50 $\mathrm{mM}$ sodium-acetate buffer ( $\mathrm{pH}$ 5.0) two times and stirred at $180 \mathrm{rpm}$ for 1 hour on ice bath to extract the samples. Solids were separated by centrifugation $\left(4 \pm 1{ }^{\circ} \mathrm{C}, 15000\right.$ rpm, 10 minutes). ${ }^{16}$ The lignocellulosic substrate was completely removed after centrifugation and the clear supernatant was obtained. The all supernatants were used for measurements of the extracellular lignocellulolytic enzyme activities and analysis's of protein, reducing sugar and nitrogen amounts.

\section{5. Assay of Enzyme Activities}

CMCase and xylanase activities were estimated by the dinitrosalicylic acid method (DNS) using $2 \%$ carboxymethyl cellulose and xylan from beechwood in the sodium citrate buffer $(50 \mathrm{mM}, \mathrm{pH} 4.8)$ as the substrates with glucose and xylose as the standards, respectively. ${ }^{17,18}$ Exoglucanase and $\beta$-glucosidase activities were monitored using $2.0 \mathrm{mM}$ p-nitrophenyl- $\beta$-cellobioside and p-nitrophenyl- $\beta$-glucopyranoside in the sodium acetate buffer (50 $\mathrm{mM}, \mathrm{pH}$ 5.0) as the subtrates, respectively. ${ }^{17}$ Lac activity was assayed by measuring the oxidation of 2, 2-amino-bis (3-ethyl benzothiazoline-6-(sulfonate) according to Johannes \& Majcherczyk with minor modifications using 5.0 mM 2,2'-azino-bis(3-ethylbenzothiazoline-6-sulphonic acid) as a substrate and sodium acetate buffer (100 $\mathrm{mM}, \mathrm{pH} 4.5) .{ }^{19} \mathrm{MnP}$ activity was measured by 2 , 6-dimethoxyphenol oxidation, $20 \mathrm{mM}$, with minor modifications in the presence of hydrogen peroxide $(4 \mathrm{mM})$ and manganese sulfate $(30 \mathrm{mM}) .{ }^{20} \mathrm{LiP}$ activity was determined by the oxidation of veratryl alcohol to veratraldehyde in the presence of hydrogen peroxide using sodium tartarate buffer (125 mM, pH 2.5). ${ }^{21}$ AAO activity was assayed spectrophotometrically using veratryl alcohol as a substrate with no adding hydrogen peroxide. ${ }^{22}$ The all enzymatic activity of $1 \mathrm{U}$ was defined as the amount of enzyme that transforms $1 \mu \mathrm{mol}$ substrate/minute in terms of volumetric activity.

\section{6. Estimation of Protein, Reducing Sugar and Nitrogen Contents}

Protein concentrations were measured using the Bradford dye-binding assay with bovine serum albumin as standard. ${ }^{11}$ Reducing sugars levels were measured by the DNS method using D-glucose as standard, according to Miller. ${ }^{23}$ Ammonium nitrogen content was assayed by the phenol-hypochlorite method using $\left(\mathrm{NH}_{4}\right)_{2} \mathrm{SO}_{4}$ as standard. ${ }^{24}$

\section{7. Statistical Analysis}

All statistical analyses were performed with the program SPSS 15.0 for Windows. The all values were the mean of three separate experiments.

\section{Results and Discussion}

Selection of appropriate lignocellulolytic organisms for SSF is one of the important factors via useful agricultural solid substrates. In this study, P.eryngii was used for enzyme producer due to its lignocelluloytic ability. ${ }^{16,25}$ The chemical compositions of untreated and pretreated peach and cherry wastes are demonstrated in Table 1. According to the obtained results, the lignin and protein concentrations for untreated peach waste were higher than that of untreated waste cherry. The lignin concentrations in both wastes were higher when compared to other lignocellulosic wastes; while the cellulose concentrations in

Table 1. The changes of main components of peach and cherry wastes after all pretreatments.

\begin{tabular}{|c|c|c|c|c|c|}
\hline & & $\begin{array}{c}\text { Protein } \\
\text { Concentration }(\%)\end{array}$ & $\begin{array}{c}\text { Cellulose } \\
\text { Concentration }(\%)\end{array}$ & $\begin{array}{c}\text { Lignin } \\
\text { Concentration }(\%)\end{array}$ & $\begin{array}{r}\text { Total Carbohydrate } \\
\text { Concentration }(\%)\end{array}$ \\
\hline \multirow{4}{*}{ 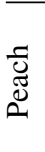 } & Untreated & $0.08 \pm 0.005$ & $4.63 \pm 0.3$ & $40.56 \pm 3.1$ & $18.59 \pm 1.1$ \\
\hline & Neutral-pretreated & $0.08 \pm 0.006$ & $4.72 \pm 0.4$ & $38.45 \pm 3.3$ & $23.46 \pm 1.8$ \\
\hline & Acid-pretreated & $0.072 \pm 0.006$ & $4.44 \pm 0.3$ & $34.07 \pm 2.6$ & $28.46 \pm 1.9$ \\
\hline & Alkaline-pretreated & $0.074 \pm 0.005$ & $4.12 \pm 0.3$ & $31.23 \pm 2.2$ & $36.06 \pm 2.8$ \\
\hline \multirow{4}{*}{$\underset{\frac{D}{U}}{\vec{D}}$} & Untreated & $0.05 \pm 0.002$ & $14.04 \pm 1.0$ & $38.8 \pm 2.6$ & $19 \pm 1.1$ \\
\hline & Neutral-pretreated & $0.05 \pm 0.004$ & $14.46 \pm 1.1$ & $37.24 \pm 3.4$ & $24.12 \pm 1.7$ \\
\hline & Acid-pretreated & $0.044 \pm 0.003$ & $13.34 \pm 0.9$ & $33.59 \pm 2.7$ & $29.74 \pm 1.8$ \\
\hline & Alkaline-pretreated & $0.047 \pm 0.002$ & $12.56 \pm 0.9$ & $30.65 \pm 2.4$ & $36.86 \pm 2.7$ \\
\hline
\end{tabular}


peach and cherry wastes were lower. ${ }^{1}$ Also, the total carbohydrate concentrations with all pretreatments in both wastes increased, while lignin concentrations in those were reduced by them. This may be due to the different structural properties of peach and cherry waste. In other words, peach wastes have softer fiber when compared to intact fiber of cherry wastes.

The reducing sugar and nitrogen levels in all growth media decreased rapidly up to $3^{\text {rd }}$ day of cultivation, but not depleted fully by P.eryngii, so that the cultivation was reached to carbon and nitrogen-limited conditions. In addition, good colonization on these wastes with control and pretreated conditions was achieved with P.eryngii, fungal growth being observed from the second day of the fermentation, and complete colonization of fungus was observed within 30 days of cultivation. Also, the protein production in P.eryngii enzyme supernatant were changed up to $187.78 \pm 8.6 \mathrm{ppm}$ for cherry wastes with and without pretreatment conditions, and this value was 1.26 -fold higher than that of control $(\mathrm{p}<0.05)$. The highest protein production was obtained in acid pretreated condition followed by alkaline, neutral pretreatment and control conditions, respectively. On the other hand, the highest protein production in control conditions of peach cultures was determined as $303.49 \pm 10.2 \mathrm{ppm}$ on $20^{\text {th }}$ day following alkaline, neutral and acid conditions, respectively. According to obtained results, the observation of the consumption of glucose and nitrogen by P.eryngii, fungal growth and protein production could be proofs that these peach and cherry wastes generated by food processing industries were good substrates for producing lignocelluloytic enzymes. Also, the use of peach and cherry wastes for economically production of these enzymes in this research has an importance and novel with regards to literature, most agro-industrial wastes used to produce lignocellulolytic enzymes by WRF have not been published since to date.

Lignocellulosic materials are recalcitrant to fungal hydrolysis due to their composite structure. ${ }^{3}$ Effective pretreatments should improve the lignocellulolytic enzyme production, but selection of these methods is great importance for economic SSF process. According to the literature, there is no study about lignocelluloytic enzyme production by P.eryngii using peach and cherry wastes with and/or without any pretreatment conditions. The activities of CMCase and xylanase showed similar trends under control and neutral-treatment condition of peach cultures. The both cellulolytic enzyme activities under control conditions of peach cultures were increased up to $5^{\text {th }}$ day of incubation, and then decreased. The highest levels of these enzymes were determined as $3.64 \pm 0.02 \mathrm{U} \mathrm{mL}^{-1}$ and $3.08 \pm 0.02 \mathrm{U} \mathrm{mL}^{-1}$, respectively. Similarly, the maximum values of CMCase and xylanase enzymes were detected as $1.30 \pm 0.01$ and $1.16 \pm 0.01 \mathrm{U} \mathrm{mL}^{-1}$ on the $3^{\text {rd }}$ day of incubation under control condition of cherry cultures. The decrements in both enzymes were observed after all treatments in peach and cherry cultures as can be seen in Figures. 1 and 2. That is, the CMCases in both cultures were produced simultaneously with xylanases by the P.eryngii during the cultivation period. Dias et al. have noted that during the SSF period the very low CMCase activities were detected in both Irpex lacteus and Euc-1 strains compared to our maximum CMCase activities of peach and cherry cultures by P.eryngii. ${ }^{26}$ In that study, $I$. lacteus and Euc-1 showed a peak of xylanase activity $\left(0.08 \mathrm{U} \mathrm{mL}^{-1}\right)$ after 10 days of incubation. On the other hand, Sharma and Arora researched which supplements were enhanced the lignocellulolytic enzyme activities of Phlebia floridensis by using paddy straw of SSF. ${ }^{27}$ According to their results, the maximum CMCase and xylanase activities were respectively recorded as 3.27 and $1.83 \mathrm{U}$ $\mathrm{mL}^{-1}$ on supplemented conditions, namely control values were below them. Naraian et al. subtracted lignocellulolytic enzyme profiles of Pleurotus spp.; Pleurotus florida, Pleurotus sajor-caju and P.eryngii. ${ }^{28}$ The CMCase and xylanase activities separately ranged from 198 to $317 \mathrm{U}$ $\mathrm{L}^{-1}$ and from 178 to $269 \mathrm{U} \mathrm{L}^{-1}$ as well as they attained very low Lac and MnP activities by these strains. Moreover, Saritha et al. illustrated that Trametes hirsuta used


Figure 1. Variations of CMCase activities depending on peach (left side) and cherry (right side) cultures. The values are the mean \pm SD for experiments of three separate experiments. 

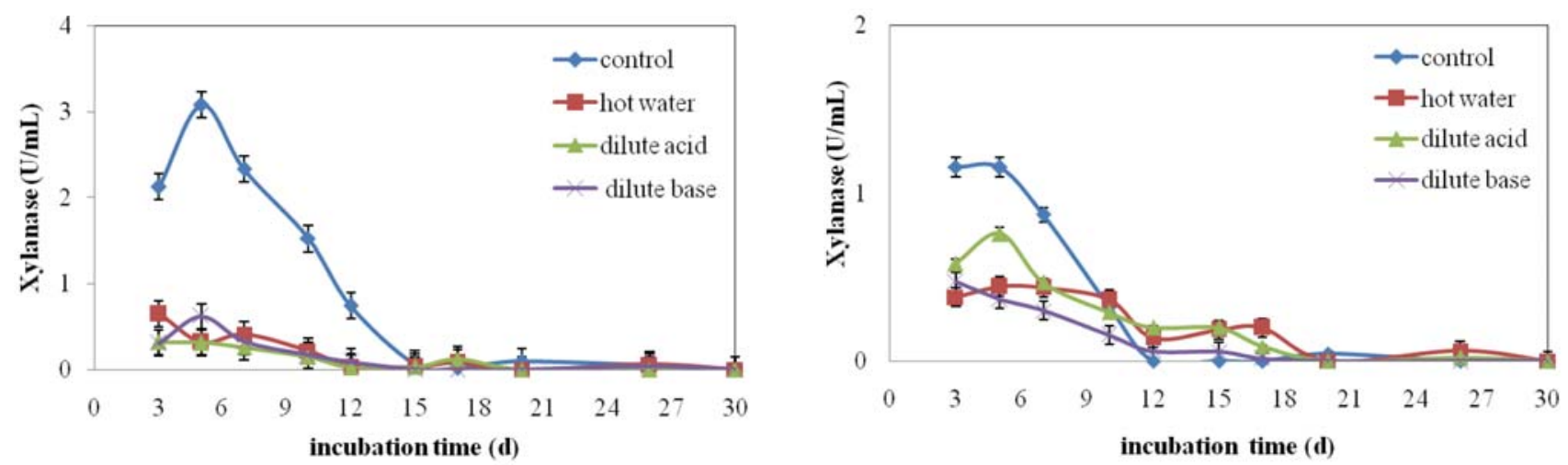

Figure 2. Variations of xylanase activities depending on peach (left side) and cherry (right side) cultures. The values are the mean \pm SD for experiments of three separate experiments.

paddy straw as a carbon source and produced the highest CMCase activity $0.71 \mathrm{U} \mathrm{mL}^{-1}$ on the $15^{\text {th }}$ day of incubation and this value was 5.13-fold lower than that of our result in obtained peach culture. ${ }^{29}$

The $\beta$-glucosidase activities were increased up to $20^{\text {th }}$ day of incubation, then decreased on both peach and cherry cultures. In peach cultures, the maximum $\beta$-glucosidase activity was attained in alkaline-treated cultures followed neutral, control and acid conditions. The maximum activity was found as $29.96 \pm 0.9 \mathrm{U} \mathrm{L}^{-1}$, which was 2.35 -fold higher than that of control $(p<0.05)$. Similar to peach culture, the highest $\beta$-glucosidase activity was obtained as $35.67 \pm 1.1 \mathrm{U} \mathrm{L}^{-1}$ in alkaline-treated of cherry cultures, which was 1.52 -fold higher than that of control $(\mathrm{p}<0.05)$. In addition, when the cherry wastes were pretreated with dilute acid solution and hot water, this enzyme activity decreased approximately $50 \%(\mathrm{p}<0.05)$. The very low exoglucanase activities were detected in all conditions of peach and cherry cultures. The exoglucanase activities in P.eryngii enzyme supernatant were changed up to $42.57 \pm 1.2 \mathrm{U} \mathrm{L}^{-1}$ for substrates peach and cherry wastes with and without pretreatment conditions during 30 days of cultivation. The highest exoglucanase activity was detected as $42.57 \pm 1.2 \mathrm{U} \mathrm{L}^{-1}$ ( $3^{\text {rd }}$ day) in control condition of peach cultures, while $13.15 \pm 0.2 \mathrm{U} \mathrm{L}^{-1}\left(20^{\text {th }}\right.$

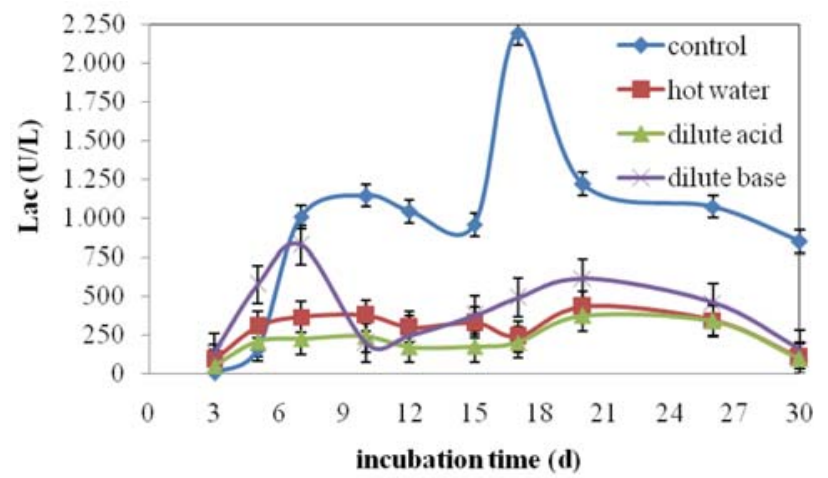

day) in alkaline pretreatment of cherry cultures. There were a few studies about exoglucanase and $\beta$-glucosidase production by Pleurotus spp. ${ }^{30}$ Similar to our activity values, $\beta$-glucosidase activities of Pleurotus spp. were extremely low. ${ }^{28}$ According to literature, fungi generally have not produced all of cellulolytic enzymes. Thus, the consortium cultures have stood out in fungal cellulolytic system and Pleurotus spp. secrete dominantly CMCase of them in peach and cherry cultures of SSF. ${ }^{31}$

The maximum Lac activities in P.eryngii enzyme supernatant ranged from $337.29 \pm 11.2$ to $2193.06 \pm 50.4$ $\mathrm{U} \mathrm{L}^{-1}$ for peach and cherry wastes with and without pretreatment conditions during 30 days of cultivation as shown in Figure 3. The maximum Lac activities in control conditions of both cultures were attained, and also they were decreased slightly under all pretreatment conditions. Also, the highest Lac activities in peach and cherry cultures were respectively determined as $2193.06 \pm 50.4 \mathrm{U} \mathrm{L}^{-1}$ $\left(17^{\text {th }}\right.$ day) and $1297.22 \pm 34.6 \mathrm{U} \mathrm{L}^{-1}\left(10^{\text {th }}\right.$ day $)$. There were insignificant differences among Lac activities in control conditions of cherry cultures on 7,10 and $12^{\text {th }}$ day of incubation ( $p>0.05)$. Stajic et al. showed that the maximum Lac activity by Pleurotus ostreatus was attained as 746.1 $\mathrm{U} \mathrm{L}^{-1}$ on the 10 day of incubation using grapevine sawdust as a substrate. ${ }^{32}$ When compared to other research of

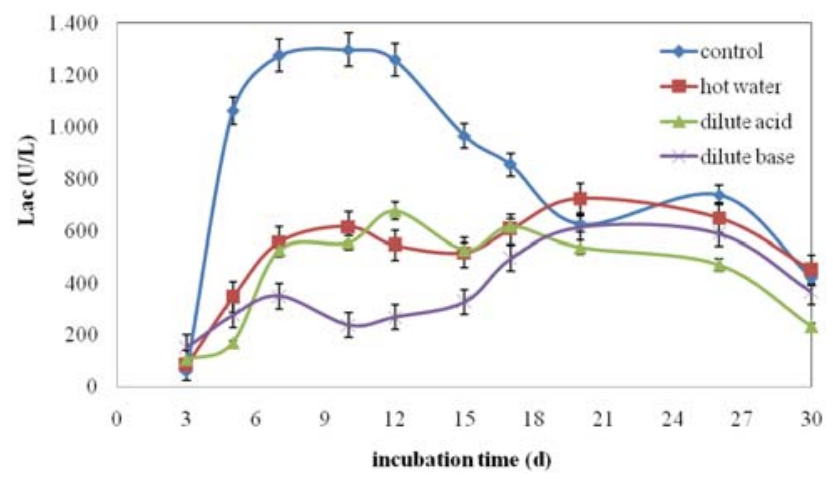

Figure 3. Variations of Lac activities depending on peach (left side) and cherry (right side) cultures. The values are the mean \pm SD for experiments of three separate experiments. 
Dias et al., ${ }^{26}$ four white rot fungi screened for Lac production during 46 days and only Euc-1 produced this enzyme (the highest activity of $100 \mathrm{U} \mathrm{L}^{-1}$; at the end of the incubation period) using wheat straw. There were insignificantly differences between the highest Lac activity obtained from grape culture with the same strain ${ }^{16}$ and peach culture in this study.

As depicted in Figure 4, the highest MnP activity was obtained under control condition followed by alkaline, neutral and acid pretreatments of peach cultures. Concurrently, the highest activity in this culture was detected on $17^{\text {th }}$ day as similar to activity of Lac. On the other hand, the maximum $\mathrm{MnP}$ activity was obtained under control condition of cherry cultures followed alkaline pretreatment. Also, they were approximately same in acid and neutral pretreatments of cherry cultures, while their levels were lower in activity of alkaline pretreatment. The highest $\mathrm{MnP}$ activity in peach cultures was found as $732.73 \pm 19.8 \mathrm{U} \mathrm{L}^{-1}$ on the $17^{\text {th }}$ day of incubation. Stajic et al. showed that the maximum MnP activity by $P$. ostreatus was attained as $10.3 \mathrm{U} \mathrm{L}^{-1}\left(10^{\text {th }}\right.$ day $)$ using grapevine sawdust as a substrate and the highest activity obtained was 71.14-fold higher than that of their results, ${ }^{32}$ while Isikhuemhen et al. researched the lignocellulolytic enzymes activities from corn stalks under SSF by white rot fungus, Lentinus squarrosulus Mnt. during 30 days of incubation, and they determined the highest $\mathrm{MnP}$ activity as $13 \mathrm{U} \mathrm{L}^{-1}$ on the $6^{\text {th }}$ day. ${ }^{33}$ Also, the highest $\mathrm{MnP}$ activity in this study was 2.68 -fold higher than the activity determined with Euc-1 strain. ${ }^{26}$ Additionally, the effects of lignocellulosic apricot and pomegranate wastes on ligninolytic enzymes by P.eryngii under SSF conditions were investigated. The highest Lac and MnP activities in this study were 1.36- and 1.26-fold higher than obtained in that study. ${ }^{34}$

Generally, there were little LiP activities in Pleurotus sp. according to literature. ${ }^{16,35}$ Insignificant levels of $\mathrm{LiP}$ activities were detected in all untreated and pretreated of both cultures with similar trends in this study. The highest value was detected as $94.09 \pm 4.1 \mathrm{U} \mathrm{L}^{-1}$ in peach cul- tures was 2.50 -fold higher than that of cherry culture under control conditions $(p<0.05)$. The declines in LiP activities were observed after pretreatment of peach and cherry cultures. Comparing peach and cherry cultures in all conditions for AAO activities, the highest value was achieved as $239.25 \pm 7.3 \mathrm{U} \mathrm{L}^{-1}$ in control condition of peach cultures as shown in Figure 5. The activities in control condition of peach cultures were continuously increased up to $17^{\text {th }}$ day of incubation, and then decreased. After pretreatment of peach cultures, the very important decreases in AAO activities were observed, approximately 9.2fold $(\mathrm{p}<0.05)$. Similar to peach cultures, the maximum AAO activity was obtained as $91.4 \pm 3.8 \mathrm{U} \mathrm{L}^{-1}$ in control condition of cherry cultures. The AAO activities under control condition of cherry cultures were increased up to $15^{\text {th }}$ day, then decreased. After pretreatment of cherry cultures, the activities were significantly decreased (nearly 4.33 -fold, especially alkaline pretreatment $)(p<0.05)$. The maximum activities in acid and neutral pretreated cherry cultures were respectively determined on $30^{\text {th }}$ and $17^{\text {th }}$ day of incubation. In addition, I. lacteus and Euc-1 strains showed their maximum LiP activities as 60 and 80 $\mathrm{U} \mathrm{L}^{-1}$ after 23 and 35 days of incubation during $\mathrm{SSF}^{26}$ these results were lower than our highest LiP activity value. When these results were compared to the results of Akpinar and Ozturk Urek, the highest LiP and AAO activities in this study were 1.82 and 1.52-fold higher than that of these attained in optimal conditions, separately. ${ }^{16}$ Moreover, Guillén et al. detected very low AAO activities by P.eryngii. ${ }^{36}$ According to literature, most WRF secrete at least two ligninolytic enzymes, whereas P.eryngii secretes three of them during SSF conditions in this study. Ruqayyah et al. studied that the ligninolytic enzyme activity of two Panus tigrinus strains on the substrates; rice straw, rice husk and cassava peel. ${ }^{37}$ According to their results, rice husk stimulated maximum Lac $\left(2556 \mathrm{U} \mathrm{L}^{-1}\right)$ and $\mathrm{LiP}\left(24 \mathrm{U} \mathrm{L}^{-1}\right)$ activities by the strains M109RQY and M609RQY, respectively. Moreover, cassava peel stimulated maximum $\mathrm{MnP}\left(141 \mathrm{U} \mathrm{L}^{-1}\right)$ activity by the strain M109RQY.


Figure 4. Variations of MnP activities depending on peach (left side) and cherry (right side) cultures. The values are the mean \pm SD for experiments of three separate experiments. 

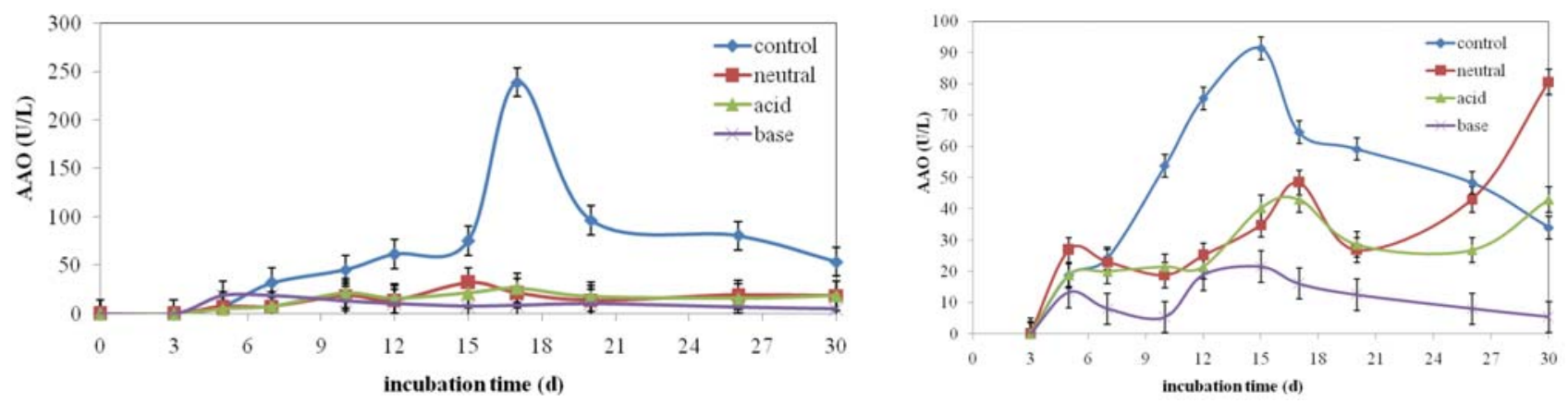

Figure 5. Variations of AAO activities depending on peach (left side) and cherry (right side) cultures. The values are the mean \pm SD for experiments of three separate experiments.

There were few studies about lignocellulolytic enzymes especially hydrolytic enzymes produced by Pleurotus species using lignocellulosic wastes according to literature. ${ }^{30}$ Namely, this study presented that $P$. eryngii could have the ability to degrade cellulose, hemicellulose and lignin in peach and cherry agroindustrial wastes due to its enzymatic complex. According to the results, there could be a relationship between secretion times of hydrolytic and ligninolytic enzymes. Firstly, the hydrolytic enzymes were produced by P.eryngii and then the ligninolytic enzyme secretion was started when other enzyme activities were lowered at the beginning time of incubation. Thus, it could be originated from the lignocellulosic structure of agroindustrial wastes. ${ }^{2,3}$ The lignocelluloytic activities were generally decreased with pretreatments methods in the presence of peach and cherry wastes as substrates. $\beta$-glucosidase and exoglucanase activities in cherry cultures were increased at alkaline pretreated conditions, while the $\beta$-glucosidase activity in peach cultures only was increased at the same conditions. On the both cultures, the CMCase and xylanase reached their highest activity at the initial days of incubation, while the highest ligninolytic enzyme activities occurred after $7^{\text {th }}$ day of incubation due to their synergetic interactions among each other. On the other hand, the maximum $\beta$-glucosidase activities were attained after the CMCase and xylanase activities were decreased. Thus, it could be held model for the synergism between CMCases, xylanases and $\beta$-glucosidases. ${ }^{38}$ In addition, the findings of higher lignocellulolytic enzyme activities under control condition of both cultures could be associated with the industrial fruit juice process steps.

In this study, the main components of these wastes were analyzed to investigation their changes during all pretreatments and the effects of the changes on lignocellulolytic enzymes production by $P$. eryngii. After all pretreatments, the chemical compositions of the wastes changed. Generally, the lignin contents decreased, while the total carbohydrate contents increased. Also, the protein contents in all conditions were approximately same with each other. The highest decreases in cellulose contents of both wastes with alkaline-pretreated were obser- ved followed by acid-pretreated. Likewise, the decreasing in most lignocellulolytic activity could be brought by the treatment of wastes and mainly depend on reducing cellulose contents after treatments. Also, it could be explained by the release of furfural and hydroxymethylfurfural derivatives from hexoses and pentoses in the lignocellulosic wastes following the pretreatment. The excess of these substances could affect the microbial growth and the production of enzymes. ${ }^{39}$ On the other hand; the efficiency of pretreatment methods depends on different factors such as composition of lignocellulosic wastes, chemicals, processing time, etc. ${ }^{40,41}$ These parameters should be optimized in subsequent experiments for higher lignocellulolytic enzyme yields.

The purpose of this study was to reveal the potentials of peach and cherry wastes as nutrient and carbonenergy sources in economic production of lignocellulolytic enzymes which are practiced on the many biotechnological applications. The fact that these cheap and easily available wastes were firstly utilized in the lignocellulolytic enzymes production having biotechnological importance plays roles in both providing economic efficiency of the process and bringing about the disposal of them. On the other hand, the P. eryngii grew on these wastes and produced high amount of lignocellulolytic enzymes when compared to literature. Pleurotus sp. appear to play a role in the production of ligninolytic enzyme rather than hydrolytic enzymes. For this reason, it is observed that peach and cherry wastes were highly potential when the efficiency of the used wastes in enzyme production is evaluated. In our another study, apricot and pomegranate agro-industrial wastes contained high lignocellulosic contents, but the enzyme productions were lower than those in this study.$^{34}$ Especially, the carbon sources constituted extremely large amounts of the process costs. ${ }^{42,43}$ and thus the utilization of these wastes by $P$. eryngii notably reduced the product costs of these enzymes. In addition, there could be unimportant effects on lignocellulolytic enzymes production using these pretreated wastes as some pretreatments methods were performed in order to ensure the availability of them by it. According to our results, the first utilization of these peach and cherry wastes by 
P.eryngii to produce lignocellulolytic enzymes with and without pretreatment reflected the significance of this study.

\section{Conclusions}

This report showed that P.eryngii can be successfully cultivated on peach and cherry lignocellulosic wastes due to its ability to produce enzymes which are essential for lignocellulose degradation, firstly. A search for newer sources of agroindustrial wastes are of great importance for the economic lignocellulolytic enzyme productions by SSF. According to the obtained results, peach and cherry wastes had high lignocellulosic contents in their composition. The pretreatment methods generally could improve the enzyme productions, however better results were obtained with untreated peach and cherry wastes except exoglucanase and $\beta$-glucosidases. Moreover, the peach wastes were more appropriate than cherry wastes for producing lignocellulolytic enzymes by P.eryngii under SSF conditions. Thus, the lignocellulolytic enzyme production cost of SSF bio-processing was reduced using the untreated peach and cherry wastes. And also, the energy to be given to the system during the pretreatment process would also be another parameter that increases the production cost. The production cost was reduced in this way, referring to the results obtained without the pretreatment. In addition, this study proved that they can be good choice as cheap agroindustrial wastes for the economic and eco-friendly production of lignocellulolytic enzymes by P.eryngii.

\section{Acknowledgements}

We are thankful to Scientific Research Project of Dokuz Eylül University (project number: 2012.KB. FEN.078). We also are thankful to Dimes, Izmir for providing lignocellulosic substrates for research.

\section{References}

1. S. I. Mussatto, J. A. Teixeira, in: A. Méndez-Vílas, (Ed.), Lignocellulose as Raw Material in Fermentation Processes: Current Research, Technology and Education Topics Applied Microbiology and Microbial Biotechnology, Badajoz, 2010, pp. 897-907.

2. C. Sánchez, Biotech. Adv. 2009, 27, 185-194. https://doi.org/10.1016/j.biotechadv.2008.11.001

3. M. Dashtban, H. Schraft, W. Qin, Int. J. Biol. Sci. 2009, 5, 578-595. https://doi.org/10.7150/ijbs.5.578

4. M. J. Maciel, A. C. Silva, H. C. T. Ribeiro, Electron. J. Biotechn. 2010, 13, 1-12.

5. C. R. Soccol, E. S. F. Costa, L. A. J. Letti, S. G. Karp, A. L.
Woiciechowski, L. P. Souza Vandenberghe, Biotechnol. Res. Innov. 2017, in press, https://doi.org/10.1016/j.biori.2017.01.002.

6. J. Barrios-González, Process. Biochem. 2012, 47, 175-185. https://doi.org/10.1016/j.procbio.2011.11.016

7. R. Samuel, M. Foston, N. Jiang, L. Allison, A. J. Ragauskas Polym. Degrad. Stabil. 2011, 96, 2002-2009. https://doi.org/10.1016/j.polymdegradstab.2011.08.015

8. C. H. , C. K. , Bioresour. Technol. 2009, 100, 866-871. https://doi.org/10.1016/j.biortech.2008.07.001

9. G. Y. S. Mtui, Afr. J. Biotechnol. 2009, 8, 1398-1415.

10. S. K. Saha, C. F. Brewer, Carbohyd. Res. 1994, 254, 157167. https://doi.org/10.1016/0008-6215(94)84249-3

11. M. Bradford, Anal. Biochem. 1976, 72, 248-254. https://doi.org/10.1016/0003-2697(76)90527-3

12. R. J. Bruce, C. A. West, Plant. Physiol. 1989, 91, 889-897. https://doi.org/10.1104/pp.91.3.889

13. I. Romero, E. Ruiz, E. Castro, M. Moya, Chem. Eng. Res. Des. 2010, 88, 633-640. https://doi.org/10.1016/j.cherd.2009.10.007

14. J. M. R. Luz, M. D. Nunes, S. A. Paes, D. P. Torres, M. C. S. Silva, M. C. M. Kasuya, Braz. J. Microbiol. 2012, 43, 15081515. https://doi.org/10.1590/S1517-83822012000400035

15. M. Stajić, L. Persky, D. Friesem, Y. Hadar, S. P. Wasser, E. Nevo, J. Vukojević, Enzyme. Microb. Tech. 2006, 38, 65-73. https://doi.org/10.1016/j.enzmictec.2005.03.026

16. M. Akpinar, R. Ozturk Urek, Prep. Biochem. Biotech. 2012, 42, 582-597. https://doi.org/10.1080/10826068.2012.673528

17. P. Baldrian, V. Valaskova, V. Merhautova, J. Gabriel, Res. Microbiol. 2005, 156, 670-676. https://doi.org/10.1016/j.resmic.2005.03.007

18. S. Kumaran, C. A. Sastry, S. Vikineswary, World. J. Microb. Biot. 1997, 13, 43-49. https://doi.org/10.1007/BF02770806

19. C. Johannes, A. Majcherczyk, J. Biotechnol. 2000, 78, 193199. https://doi.org/10.1016/S0168-1656(00)00208-X

20. H. Kamitsuji, Y. Honda, T. Watanabe, M. Kuwahara, Appl. Microbiol. Biot. 2004, 65, 287-294. https://doi.org/10.1007/s00253-003-1543-9

21. M. Tien, T. K. Kirk, Methods Enzymol. 1988, 161, 238-249. https://doi.org/10.1016/0076-6879(88)61025-1

22. K. Okamoto, H. Yanase, Mycoscience. 2002, 43, 391-395. https://doi.org/10.1007/S102670200057

23. G. L. Miller, Anal. Chem. 1956, 31, 426-428. https://doi.org/10.1021/ac60147a030

24. M. W. Weatherburn, Anal. Chem. 1967, 39, 971-974. https://doi.org/10.1021/ac60252a045

25. X. Q. Dong, J. S, Yang, N. Zhu, E. T. Wang, H. L. Yuan, Bioresour. Technol. 2013, 131, 443-451. https://doi.org/10.1016/j.biortech.2012.12.182

26. A. A. Dias, G. S. Freitas, G. S. M. Marques, A. Sampaio, I. S. Fraga, M. A. M. Rodrigues, D. V. Evtuguin, R. M. F. Bezerra, Bioresour. Technol. 2010, 101, 6045-6050. https://doi.org/10.1016/j.biortech.2010.02.110

27. R. K. Sharma, D. S. Arora, Int. Biodeter. Biodegr. 2011, 65, 990-996. https://doi.org/10.1016/j.ibiod.2011.07.007 
28. R. Naraian, D. Singh, A. Verma, S. K. Garg, J. Environ. Biol. 2010, 31, 945-951.

29. M. Saritha, A. Arora, L. Nain, Bioresour. Technol. 2012, 104, 459-465. https://doi.org/10.1016/j.biortech.2011.10.043

30. M. Téllez-Téllez, R. Díaz, C. Sánchez, G. Díaz-Godínez, Afr. J. Microbiol. Res. 2013, 7, 276-281. https://doi.org/10.5897/AJMR12x.016

31. Y. Chi, A. Hatakka, P. Maijala, Int. Biodeter. Biodegr. 2007, 59, 32-39. https://doi.org/10.1016/j.ibiod.2006.06.025

32. M. Stajíc, J. Vukojević, A. Knežević, I. Milovanović, Bioresources. 2013, 8, 3027-3037. https://doi.org/10.15376/biores.8.2.3027-3037

33. O. S. Isikhuemhen, N.A. Mikiashvili, C.O. Adenipekun, E.I. Ohimain, G. Shahbazi, World. J. Microbiol. Biotechnol. 2012, 28, 1961-1966.

https://doi.org/10.1007/s11274-011-0998-6

34. M. Akpinar, R. Ozturk Urek, Prep. Biochem. Biotech. 2014, $44,772-781$. https://doi.org/10.1080/10826068.2013.867870

35. Y. Fukushima, T. Kirk, Appl. Environ. Microb. 1995, 61, 872-876.
36. F. Guillén, A. T. Martínez, M. J. Martínez, C. S. Evans, Appl. Microbiol. Biotechnol. 1994, 41, 465-470.

37. T. I. D. Ruqayyah, P. Jamal, Z. Alam, E. S. Mirghani, J. Environ. Manage. 2013, 118, 115-121. https://doi.org/10.1016/j.jenvman.2013.01.003

38. L. R. Lynd, P. J. Weimer, W. H. Zyl, I. S. Pretorius, Microbiol. Mol. Biol. R. 2002, 66, 506-577. https://doi.org/10.1128/MMBR.66.3.506-577.2002

39. A. M. J. Kootstra, H. H. Beeftink, E. L. Scott, J. P. M. Sanders, Biotechnol. Biofuels. 2009, 2, 1-14. https://doi.org/10.1186/1754-6834-2-31

40. Y. C. Dong, Y. N. Dai, T. Y. Xu, J. Cai, Q. H. Chen, Bioprocess. Biosyst. Eng. 2014, 37, 755-64. https://doi.org/10.1007/s00449-013-1045-9

41. T. López-Arenas, P. Rathi, E. Ramírez-Jiménez, M. SalesCruz, Comput. Aided. Chem. Eng. 2010, 28, 979-984.

42. Z. Velioglu, R. Ozturk Urek, Appl. Biochem. Biotechnol. 2014, 174, 1354-1364. https://doi.org/10.1007/s12010-014-1136-3

43. H. Li, R. Zhang, L. Tang, J. Zhang, Z. Mao, Chin. J. Chem. Eng. 2015, 23, 227-233.

https://doi.org/10.1016/j.cjche.2014.11.001

\section{Povzetek}

Gliva Pleurotus eryngii je bila inkubirana na agroindustrijskih trdnih odpadkih breskve in češnje. Potekala je 30-dnevna fermentacija brez oziroma z predobdelavo substrata z razredčeno kislino, lugom in vročo vodo pred inkubacijo. Maksimalni aktivnosti karboksimetil celulaz in ksilanaz sta se pojavili tretji in peti dan pri obeh substratih, maksimalni aktivnosti lakaz in mangan peroksidaz pa sta bili doseženi sedemnajsti dan. Predobdelava je v glavnem imela negativen učinek na sintezo ligninolitičnih encimov. Najvišje encimske aktivnosti so bile dosežene na odpadkih breskve. Rezultati kažejo, da ti odpadki lahko služijo kot alternativen in ekonomičen vir energije za produkcijo velikih količin ligninolitičnih encimov. 